\title{
Mangabeira Latex and Rubber
}

\author{
By Norman Bekkedahl and Waldemar Saffioti ${ }^{2}$
}

\begin{abstract}
The tree Hancornia speciosa, more commonly known as the mangabeira, which grows in several of the tropical states of Brazil, yields a rubber-containing latex. This tree is very well known for the delicious fruit (mangaba) it bears, but it does not have such a good reputation for the quality of rubber it produces. The natives of Brazil coagulate this rubber by means of solutions of alum or sodium chloride. It has been found, however, from this investigation that if these coagulating agents are replaced by dilute hydrochloric acid or by the latex from another tree, the caxinguba (Ficus anthelmintica), a rubber of much improved properties can be produced.
\end{abstract}

\section{Introduction}

The mangabeira (Hancornia speciosa) is a small tree, or large shrub, of the Apocynaceae family. It is indigenous to the eastern and southern states of Brazil and also to parts of the Amazon Valley. It is cultivated mostly for its fruit (mangaba), which is edible and has an excellent taste. When an incision is made into the bark of this tree, however, it yields a rubber-containing latex. Its rubber is known usually as mangabeira rubber or Pernambuco rubber.

Before World War II there was very little commercial production of mangabeira rubber, although it had been marketed to some extent before plantation rubber became prominent and when the price of crude rubber was very high. Several factors accounted for this low production. The most commonly used natural rubber, which is obtained from the seringueira, or Pará, rubber-tree (Hevea brasiliensis), ${ }^{3}$ is superior both in quality

\footnotetext{
1 The experimental work for this paper was performed during 1943 and 1944 at the Instituto Agronômico do Norte, at Belém do Pará, Brazil, where the senior author was detailed for the purpose of establishing a rubber laboratory for the Brazilian Government. This article is also to be published as a technical bulletin of the Instituto Agronômico do Norte, entitled "Latex e Borracha de Mangabeira”, I. A. N. Boletim Técnico No. 11.

${ }_{2}^{2}$ Present address: Alameda Glette 463, São Paulo, Brazil.

${ }^{3}$ Hevea brasiliensis is the botanical name for the Pará rubber tree, named after the port of Pará at the mouth of the Amazon River through which all the rubber passed in the early days of wild-rubber production. In Brazil this tree is more commonly known as the seringueira, and this term is often used in this paper. It must not be confused with seringueiro, which is the term applied to the person who taps the seringueira and processes its latex into rubber.
}

and as a general-purpose rubber. The more effective tapping methods for the manabeira are much different from those for the seringueira and have not yet been as well developed. The methods for coagulating rubber from the latex of mangabeira are somewhat different from those of the seringueira and are not generally as well known to the natives or producers.

During the war, however, efforts were made to obtain all the natural rubber possible, almost regardless of cost or quality. According to information made available by E. G. Holt $[1],{ }^{4}$ who had charge of all statistical records of the Rubber Development Corporation, mangabeira rubber was produced during the war years to the total extent of about 2,000 to 2,500 tons. The use, and consequently the production, of this rubber will probably decrease again to a negligible quantity when normal conditions are resumed unless improved processes are developed for tapping the mangabeira tree and for coagulating the rubber from the latex, or unless special uses are found or developed that require the softness or other properties peculiar to this rubber.

A thorough study of tapping methods could undoubtedly bring about a greater yield of latex per tree per year with less effort on the part of the producer. The present methods of tapping in-

\footnotetext{
${ }^{4}$ Figures in brackets indicate the literature references at the end of this
} paper. 
volve either the cutting of many $V$-notches in the bark of the tree, not only on the main trunk but also on all the larger branches, or the cutting of spiral grooves in the main trunk, which are fed from straight cuts on the branches. The latex flows very freely from these wounds into cups placed just below the V's or at the bottom of the spiral, and within an hour or two a liter or more of latex may be obtained from a single tree. This process is quite different from the tapping of the seringueira, or Pará, rubber-tree, which is usually tapped by making only one straight slanting cut at a time on the trunk of the tree within a few feet of the ground. Each tapping of the Pará tree may yield an average of only about 50 to $100 \mathrm{ml}$ of latex, but this cutting is repeated usually every second day throughout most of the year. The mangabeira tree, like the castilloa, does not produce such a copious quantity of latex at each tapping if the process is repeated at these frequent intervals. A. W. J. Dyck [2] has observed that in Bahia the mangabeira trees are tapped generally no more than two to three times per year. The maximum quantity of rubber that a mangabeira tree can produce during a full year of tapping is not known, but under proper conditions it may possibly yield as much as, if not more than, the Hevea. At least, the amount of labor connected with the tapping of a mangabeira tree over a period of a year would be considerably less than that with the Hevea.

The coagulating characteristics of mangabeira latex are much different from those of the seringueira latex. All the mangabeira latices studied by the present authors were found to be very stable with regard to spontaneous coagulation. No coagulations took place from long-time standing under the atmospheric conditions of the tropics. No putrefaction took place from bacterial action. No coagulation occurred by the addition of acetic or formic acid in concentrations used on the plantations for the coagulation of Hevea latex, which is equivalent to about $1 \mathrm{~g}$ or less of the concentrated acid per liter of the latex. However, if 100 times this quantity of glacial acetic acid is added to undiluted mangabeira latex, the rubber will coagulate. The addition of this large quantity of acid is, of course, not economical or practical on a commercial basis.

Because of possible variations that may occur in the same species of tree in different localities, there may be some variations in the minimum quantities of coagulants required for quantitative coagulation. All the latices studied in this investigation, which were obtained from areas adjoining the lower Amazon, were found to be very stable. Several samples of mangabeira latex obtained in the Amazon Valley remained stable and fresh after more than a year of standing without the addition of a preservative. Dyck [2], who studied methods of coagulating mangabeira latex he obtained from the state of Bahia, on the east coast of Brazil, reports that mangabeira latex is much more stable than Hevea latex. Guimaraes and Chaves [3], who worked with mangabeira latex from southern Brazil, state that no coagulation took place either by fermentation or by the addition of enzymes. It is doubtful, then, whether there is sufficient variability in latices from different areas that would appreciably alter the conclusions arrived at from a study of coagulants from the commercial viewpoint.

The natives of Brazil, who coagulate rubber from Pará latex by means of smoking the latex on the end of a stick or paddle, have found that this procedure is not as satisfactory a method for the latex of the mangabeira. They have, however, discovered that ordinary table salt or alum solutions in moderate quantities will separate the rubber from mangabeira latex, and therefore they use these coagulants in their processing operations.

Mangabeira rubber seems to have gained a bad reputation with the consumer, especially as to its aging qualities. It was therefore thought worthwhile to make a search for other coagulants and to study the rubber produced under various processing conditions. At the same time it was decided to make a few simple analyses and tests on the latex and the rubber of the mangabeira.

\section{Samples of Latex}

All the latex samples used in these experiments were obtained from mangabeira trees found in various parts of the lower Amazon Valley. On most occasions representatives were sent out from the rubber laboratory to these areas to purchase the latex. The producers, in all instances, claimed there had been no dilution of their latices, either through intention or by rainfall. However, in order to be sure of authentic 
material, latex that had undergone no adulteration or dilution, for at least some of the experiments, the authors on several occasions procured their own samples, conducting all the operations themselves, such as tapping the trees, collecting the latex, and transporting it to the laboratory. They collected their samples on the Island of Marajó. The most concentrated sample came from some mangabeira trees near the city of Ponte de Pedras on this same island. In each case about 5 gallons of the latex was obtained for experimentation.

\section{Experimental Procedure}

Immediately after reaching the laboratory the latex samples were strained through fine Monelmetal sieves in order to remove dirt, bark, and other solid foreign matter that may have been present. Before portions of the samples were removed for experimentation, the latex was stirred well in order to be sure of a homogeneous mixture.

\section{Method for Measuring Density}

All density measurements on the latex samples were made by means of a glass hydrometer that had a range from 0.940 to 1.000 . The markings on the scale were 0.001 unit, and it was fairly easy to estimate the next place to within 2 or 3 units. The hydrometer had previously been calibrated by measuring the densities of alcoholwater mixtures, the true densities of which had been determined by weighing known volumes. All density measurements reported in this paper are corrected to or measured at the temperatures indicated, and the units are given in grams per milliliter $(\mathrm{g} / \mathrm{ml})$.

For several samples of latex, density measurements were made at various temperatures in order to obtain a value for the thermal coefficient of expansion. For these experiments a portion of the sample was placed in a 2-liter cylinder and then cooled for about 24 hours in a refrigerator to about $8^{\circ} \mathrm{C}$. Then, with constant and rapid agitation (by means of a motor-stirrer) between hydrometer readings, density-temperature data were taken. The warming of the solution was either natural or by an electric immersion heater controlled by a variable-ratio autotransformer.
The usual temperature rise was $10^{\circ} \mathrm{C}$ per hour or slower.

\section{Methods for Determining Rubber Content of Latex}

Analyses were made on several samples of the mangabeira latex for both the total solids (TS) and the dry rubber content (DRC).

In determining the TS content, a sample of the latex was weighed before and after drying on the surface of a glass or glazed porcelain plate. It was found most convenient to use plates thin enough for low weight and small enough to fit on the pan of an analytical balance. The latex sample was weighed from a covered weighing flask because evaporation of even a small portion of the latex affects the accuracy of the analytical results. The plates were weighed before the latex was added and after the drying of the latex. The latex should not form too thick a layer on the plate for proper evaporation. Preliminary drying of the latex may take place in the room, either free or by forced circulation of air, but final drying must take place in an oven. A temperature of about $70^{\circ} \mathrm{C}$ is quite suitable for the drying. In the present investigation, the weight of the samples ranged from 0.5 to $25 \mathrm{~g}$. For the smaller samples much more care is required, and it is recommended that larger samples be used. Samples of about $10 \mathrm{~g}$ each can be handled conveniently and give excellent results.

For the determination of the DRC of the latex several coagulants were tried in varying proportions. Weighed samples of the latex, usually about $100 \mathrm{~g}$ each, were placed in crystallizing dishes and the coagulating agents added with stirring. In some cases the latex had been diluted with water previous to the addition of the coagulant. After coagulation was complete, which could easily be determined by the clarity of the serum, and the coagulum was strong enough to handle, it was passed several times between laundry-type wringer rolls for sheeting, during which process plenty of water was used for washing, and then it was hung up to air-dry for several hours. The rubber was then passed through a laboratory-size mixing mill for creping. The resulting creped rubber was placed in an oven at $70^{\circ} \mathrm{C}$ until dry. In order to make sure that the samples were dry, they were usually folded and 
passed through the mill again to give a fresh surface before the second oven-drying.

A large number of coagulants were originally tried, but only a few of these showed any promise of being satisfactory. Therefore, most of the study of coagulating agents was limited to a few, namely, acetic acid, alum solution, sodium chloride solution, hydrochloric acid, and latex of the caxinguba tree (Ficus anthelmintica).

\section{Methods for Coagulating Latex}

In addition to the methods of coagulation mentioned in the previous section, which were made for the purpose of analyses only, studies were also made on methods which might be applicable on a commercial scale. For this purpose the coagulations were performed in either galvanizediron or wooden containers of about 24 by $35 \mathrm{~cm}$ dimension and $12 \mathrm{~cm}$ in height.

One liter of the undiluted latex was used for each experiment. Sometimes the latices were diluted with water previous to the addition of the coagulants. Stirring took place during the addition of the coagulating agent. After the coagulum had been allowed to stand a sufficient time in order for it to develop strength enough to be handled, it was passed several times between wringer rolls for the purpose of pressing into a thinner sheet. Between the pressing operations the rubber was washed thoroughly. It was next passed between ribbed rolls from which the rubber emerged in the usual form of plantation ribbed smoked sheet. It was then either hung up in a ventilated drying room at $40^{\circ} \mathrm{C}$, or placed in a smoke hut at the same temperature until dry. These drying operations usually required from 4 to 7 days.

\section{Methods of Chemical Analysis}

Only a few different chemical analyses were made on the mangabeira rubber. It was not necessary to determine the moisture content because all the samples were previously dried. Ash determinations were made by igniting the samples carefully in a muffle furnace according to the directions given in section 17, of method D297-41T of the ASTM [4]. The resin content of the rubber was assumed to be the same as the acetone-extract determined by the procedure in section 11 also given in method D297-41T.

\section{Methods of Vulcanization and Testing}

Samples of the mangabeira rubber, usually 250 to $300 \mathrm{~g}$ each, were compounded on a 6 by 12 -in. laboratory-size mixing mill according to Formula II of the Crude-Rubber Committee of the Rubber Division of the American Chemical Society [5]:

Rubber
Zinc oxide
Sulfur
Stearic acid
Mercaptobenzothiazole

The compounded rubber was vulcanized at $141^{\circ} \mathrm{C}$ in standard molds of the type described in method D15-41 of the ASTM [4]. Samples were vulcanized for various periods of time, ranging from 15 minutes to several hours, in order to include the optimum conditions of vulcanization for each sample of rubber as determined by the highest tensile strength. In all cases the time for vulcanization of the mangabeira rubber at $141^{\circ} \mathrm{C}$ to the optimum conditions was either 60 or $90 \mathrm{~min}$ utes, more frequently the latter. This rubber therefore cures slightly slower than the Pará rubber. The vulcanized rubber sheets were cut into dumbbell-shaped specimens, and the tensile properties were measured by means of a Scott tensile tester. All tensile values are reported in kilograms per square centimeter $\left(\mathrm{kg} / \mathrm{cm}^{2}\right)$ of original cross section of the specimen. When aging experiments were performed, some of the dumbbell specimens were aged in a pressure bomb for 48 hours at $70^{\circ} \mathrm{C}$ and under $300 \mathrm{lb} /$ in. $^{2}\left(21.1 \mathrm{~kg} / \mathrm{cm}^{2}\right)$ of oxygen pressure. The rubber specimens were then tested for tensile strengths and the results compared with those of the unaged specimens.

\section{Results and Discussion}

\section{Total Solids and Rubber in Latex}

The true values of the DRC of several of the latices, which are determined by the method of complete coagulation, are given in column 7 of table 1. Column 8 contains the corresponding values for the TS, as determined by the method of evaporation.

Eight different samples of latices are designated A through $\mathrm{H}$. The sample $0.5 \mathrm{H}$ is latex $\mathrm{H}$ diluted 1:1 with water. Sample 37 is a theoretical latex having a density of $0.9748 \mathrm{~g} / \mathrm{ml}$ at $30^{\circ} \mathrm{C}$. Its purpose will be seen later, but it can have no 
TABLE 1.-Densities, coefficients of expansion, and rubber content of several mangabeira latices

\begin{tabular}{|c|c|c|c|c|c|c|c|}
\hline \multirow{2}{*}{$\begin{array}{l}\text { Sample or } \\
\text { substance }\end{array}$} & \multicolumn{3}{|c|}{ Densities, g/ml at- } & \multirow{2}{*}{$\begin{array}{l}\text { Coeffi- } \\
\text { cient, } \\
\frac{1}{V}\left(\frac{d V}{d T}\right)\end{array}$} & \multicolumn{2}{|c|}{$\mathrm{DRC}$} & \multirow{2}{*}{$\begin{array}{l}\text { TS by } \\
\text { evapo- } \\
\text { ration } \\
\text { method }\end{array}$} \\
\hline & $20^{\circ} \mathrm{C}$ & $25^{\circ} \mathrm{C}$ & $30^{\circ} \mathrm{C}$ & & $\begin{array}{l}\text { Den- } \\
\text { sities }\end{array}$ & $\begin{array}{l}\text { ula- } \\
\text { tion }\end{array}$ & \\
\hline A & 0.9877 & 0. 9861 & 0.9844 & $34 \times 10^{-5}$ & $\begin{array}{c}W t \% \\
28.8\end{array}$ & $\begin{array}{r}W t \% \\
25.5\end{array}$ & $W t \%$ \\
\hline $\mathrm{B}_{\ldots}$ & .9856 & .9838 & .9819 & 38 & 30.9 & 27.4 & 30.1 \\
\hline $\mathrm{C}_{\ldots} \ldots$ & .9868 & .9848 & .9827 & 42 & 30.3 & 30.4 & W \\
\hline D $\ldots \ldots$ & .9875 & .9856 & .9836 & 40 & 29.5 & 32.1 & 36.1 \\
\hline $\mathrm{E}_{\ldots} \ldots$ & .9828 & .9810 & .9791 & 38 & 33.3 & 33.1 & 35.5 \\
\hline $\mathrm{F}_{\ldots} \ldots$ & .9815 & .9794 & .9771 & 45 & 35.0 & 34.0 & 36.8 \\
\hline G.......... & .9827 & .9806 & .9783 & 45 & 34.0 & 37.3 & . \\
\hline $\mathrm{H}$ & .9777 & .9755 & .9730 & 48 & 38.5 & 39.7 & 43.0 \\
\hline $0.5 \mathrm{H} \ldots$ & .9876 & .9864 & .9851 & 25 & 28.2 & 19.8 & 21.5 \\
\hline $37 \ldots$ & .9787 & .9768 & .9748 & 40 & 37.0 & 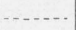 & \\
\hline Water & .9982 & .9971 & .9957 & 25 & 19.5 & 0 & 0 \\
\hline Serum $\ldots$ & $\ldots$ & ....... & 1. 0200 & & 0 & 0 & \\
\hline $\begin{array}{l}\text { Disperse } \\
\text { phase. }\end{array}$ & . & ....... & 0.9064 & & 100 & 100 & 100 \\
\hline Rubber & .9142 & .9110 & .9077 & 65 & 98.7 & 100 & 100 \\
\hline
\end{tabular}

experimentally determined DRC and TS. The water, as shown in the table, of course, runs zero in DRC and TS. The serum of any latex is also zero in DRC. The serum probably would have a TS content of about 2 to 3 percent, but this determination was not made experimentally. The disperse phase is assumed to be all rubber, and therefore is 100 percent in both DRC and TS.

As with latex from the Pará tree, the TS of mangabeira latex is 5 to 10 percent greater than the DRC. The serum contains some nonrubber constituents that are not separated from it by the addition of the coagulating agents in the determination of the DRC.

\section{Density and its relation to rubber content}

Because of the noncommercial value of mangabeira rubber in the past there has been very little scientific information published about this rubber. The present authors were unable to find in the literature any data on the physical constants or properties of the rubber or latex. It has been found from experiments performed in this investigation, however, that the DRC and density values for mangabeira latex are very similar to those for the Pará latex. Therefore, for comparisons, a brief survey of a few of the more prominent published investigations made on the Hevea latices will be included in the discussion.

For many years the plantations of the Far East, for control purposes in the field and in the processing factories, have been using density measure- ments of their Hevea latices as a means of determining their DRC. As latex is composed of rubber particles suspended in a serum (and not in true solution) the law of mixtures has been assumedthe volume percentage of rubber in the latex is a linear function of the density.

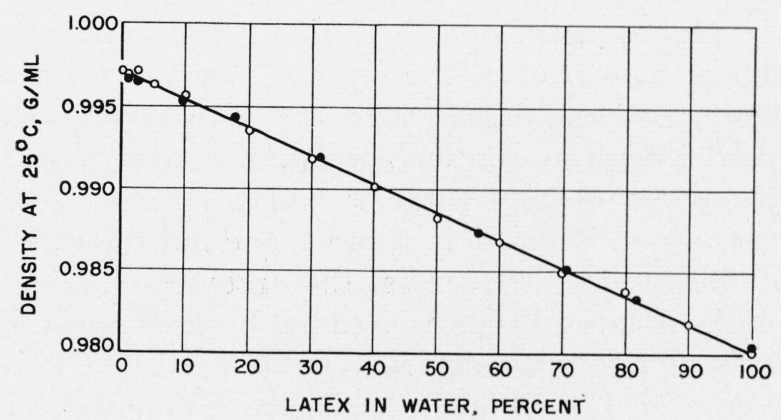

FIgURE 1.-Density values of a sample of mangabeira latex at different dilutions with water.

The two types of points indicate separate experiments on the same batch of latex.

In order to test the validity of this law of mixtures for latex, an experiment was performed in which density measurements were made on a sample of mangabeira latex for a series of dilutions. The results are plotted in figure 1 . It can be seen that the concentration of the rubber, or $\mathrm{DRC}$, is a linear function of the density, the latter value, after continued dilution, approaching that for water $\left(0.9971 \mathrm{~g} / \mathrm{ml}\right.$ at $\left.25^{\circ} \mathrm{C}\right)$. This curve could therefore be used to determine the amount of dilution of this particular sample of latex, but it could not be used to determine the DRC of other samples of latex because the rubber particles are not suspended in water but in a serum whose density is not the same as that for water.

Various authors have made contributions to the study of density values versus DRC. The results disagree with each other to some extent, but this disagreement is probably within the variations found between different samples of latex. Very few of the authors have defined their units of density or specific gravity, nor have they recorded the temperatures at which these determinations were made. DeVries [6] states that the specific gravity of the serum of Hevea latex varies between 1.016 and 1.025 for different latices, but for calculations he uses a value of 1.020. He accepts a specific gravity of 0.914 for the rubber phase in the latex. The curve on page 4 of his book [6] is made linear between these two values on a weight- 
percentage basis, whereas it should have been on a volume-percentage basis in order to comply with the law of mixtures.

It seems to have been common practice on plantations, because of the high viscosity of undiluted latex, to dilute the latex $1: 1$ with water before measuring the density, and then to multiply the resulting value of DRC by 2 in order to obtain the DRC of the original latex. DeVries points out that this procedure gives erroneous results because continuous dilution with water causes the density curve to approach the value of water, as is shown in figure 1, and not the value of the serum. Of course, the accuracy of these results in most instances need not be great because latex is not generally sold on this basis. This type of analysis is made on the plantation in order to determine quickly whether or not the coolies are diluting the latex before bringing it in, and also in order to determine the approximate extent of dilution of the latex in preparation for coagulation.

Hauser [7] states that for the calculations of DRC in the average latex a value of 0.914 may be assumed for the specific gravity of the disperse phase, thus giving it a DRC value of $91.4 \mathrm{~g} / 100$ $\mathrm{ml}$. Hauser's curve gives the rubber content in grams per $100 \mathrm{ml}$ on a linear basis between this point and one at 1.020 specific gravity for the pure serum. Scholz and Klotz [8] found a lower value of 0.901 for the disperse phase.

Rhodes [9], who experimented with about 850 different samples of latex and probably made more precise measurements under better controlled conditions than the other investigators, extrapolated an experimentally obtained linear curve of specific gravity versus rubber content to values below 28 percent and above 50 percent of rubber on the weight basis. From this he obtained a density of 1.0177 for the pure serum and 0.9019 for that of the rubber phase. DeVries [10] made some calculations by using part of the data obtained by Rhodes, and replotted the DRC on a volume basis instead of a weight basis. From these he obtained 1.020 and 0.9065 as the specific gravities of the serum and the disperse phase, respectively. Rhodes [11] later agreed with the latter method of calculation, and recomputed all of his previous data, arriving at the values of 1.0200 and 0.9064 for the extreme points on the curve. Stevens and Stevens [12] prepared a table comparing the values obtained by the Rubber Research Institute of Malaya (Rhodes' values) and their own values at the Rubber Trade Association and found them to be in very close agreement.

By repeated electrophoretic depositions of rubber from latex, and redispersing the rubber in ammoniacal solutions, Schmidt and Stamberger [13] prepared a rubber dispersion free from its original serum. On progressive dilutions of this final dispersion density values were determined, and an extrapolation of the curve gave a density of 0.905 for the disperse phase at $18^{\circ} \mathrm{C}$. After drying the disperse phase, its density was measured by a direct determination as 0.909 at the same temperature. Using $0.000658 / \mathrm{deg} \mathrm{C}$ as the volume-temperature coefficient of expansion for rubber [14], these densities are calculated to be equivalent to 0.901 and 0.905 , respectively, at $25^{\circ} \mathrm{C}$. These do not agree very well with the density value of $0.911 \mathrm{~g} / \mathrm{ml}$ obtained by Curtis, McPherson, and Scott [15], which has been suggested by Wood [16] as the best value determined for rubber. The previously mentioned values of 0.905 and 0.909 at $18^{\circ} \mathrm{C}$ also are equivalent to 0.898 and 0.902 , respectively, for $30^{\circ} \mathrm{C}$, which is the temperature probably close to the average at which the measurements of density are made on plantations.

The density of $0.911 \mathrm{~g} / \mathrm{ml}$ for rubber at $25^{\circ} \mathrm{C}$, which was previously referred to as the probable best value, is equivalent to $0.908 \mathrm{~g} / \mathrm{ml}$ at $30^{\circ} \mathrm{C}$. This value is in quite close agreement with the value of 0.9064 obtained by Rhodes, who reported that all his measurements were made at $29^{\circ}$ to $30^{\circ} \mathrm{C}$. As Rhodes' value comes closest to that obtained by the direct measurement of density of rubber, and as he seems to have done very careful work on many samples of latex of variable composition, his results should be the most acceptable at present. There appears to be no doubt as to the density of the average serum being 1.020. From the equation given by Rhodes, the following can be derived:

$$
\mathrm{DRC}=\frac{0.9245-0.9064 D}{0.1136 D},
$$

in which $D$ is the density of the latex in grams per milliliter at $30^{\circ} \mathrm{C}$.

Although all of the authors admit quite a large variation or deviation in the individual results, probably because of interfacial tensions producing 
a frictional effect, Hauser [7] claims this frictional effect can be eliminated by the addition of a small quantity of sodium hydroxide or potassium hydroxide, thus resulting in a much better value for the DRC. However, no hydroxide was added to any of the latices studied in this investigation.

In figure 2 are plotted the values of densities of several samples of mangabeira latex at temperatures ranging from about $10^{\circ}$ to $45^{\circ} \mathrm{C}$. It was not possible in most cases to make measurements above $35^{\circ} \mathrm{C}$ because some rubber coagulated on the blades of the stirring propeller. This separation of the rubber from the latex, of course, changes the DRC and therefore the density of the latex.

From the curves in figure 2 the density values of the several samples of latex can easily be read at various temperatures. Values of the densities at $20^{\circ}, 25^{\circ}$, and $30^{\circ} \mathrm{C}$ for the various samples of latex have been determined from a large-scale drawing of these curves and are recorded in columns 2, 3, and 4, respectively, of table 1 . Densities are reported at $25^{\circ} \mathrm{C}$ because this temperature has become the most common for reporting values of physical constants. The $30^{\circ} \mathrm{C}$ values are reported because they come closer to being those representing measurements made in the tropical climates of the rubber plantations.

From the densities at $20^{\circ}$ and $30^{\circ} \mathrm{C}$, fairly good values of the volume coefficients of expansion can be calculated for $25^{\circ} \mathrm{C}$. These volume or density coefficients,

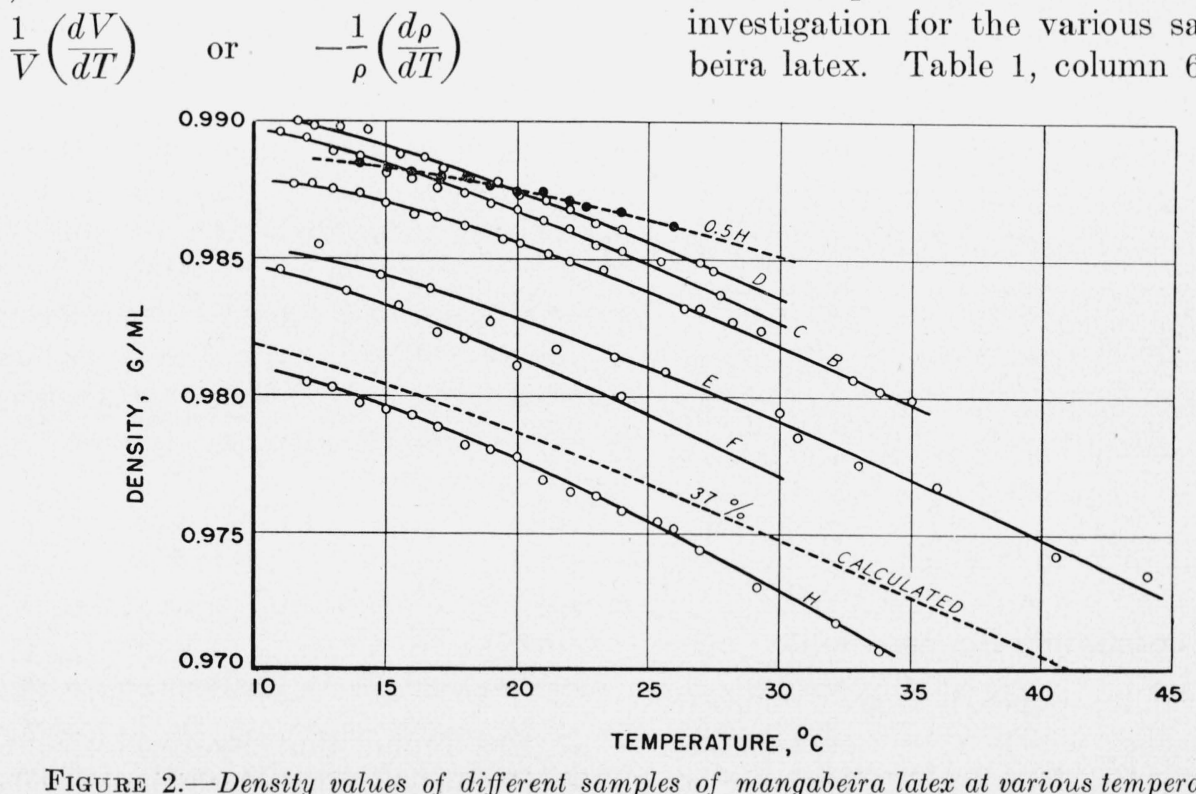

FIGURE 2.-Density values of different samples of mangabeira latex at various temperatures. per degree centigrade, are shown in column 5 of table 1. The average value for the eight samples of latex, A through $\mathrm{H}$, is $0.00041 / \mathrm{deg} \mathrm{C}$. It can be seen that the dilution of a latex (sample $0.5 \mathrm{H}$ ) greatly decreases this coefficient.

In a manner somewhat similar to the dependency of the density of a latex on its DRC, the volume coefficient of expansion should also be dependent on the DRC. In applying this assumption, however, one must know the coefficient for serum and for rubber. The value for rubber, as previously mentioned, is known to be $0.000658 / \mathrm{deg}$ $\mathrm{C}$, but that for the serum has never been measured. As an approximation to the correct value, the coefficient of water, $0.00025 / \mathrm{deg}$, will be used here. Assuming sample 37 to contain 37 percent DRC and 63 percent water, its coefficient is calculated to be 0.00040 , which is in good agreement with the average of those measured. It can be seen from the lack of order of the values of the coefficients in column 5 of table 1 that this measurement is not sufficiently precise to allow a calculation of even an approximate value for the DRC. However, it may be of value to determine whether a latex sample is naturally low in DRC or whether it has been greatly diluted with water. This condition of the latex could probably better be determined from DRC and density measurements.

Figure 3 shows the relation between the density of a sample of latex and its DRC calculated from the equation previously given. The points represent experimental values obtained in this investigation for the various samples of mangabeira latex. Table 1 , column 6 , gives the DRC 


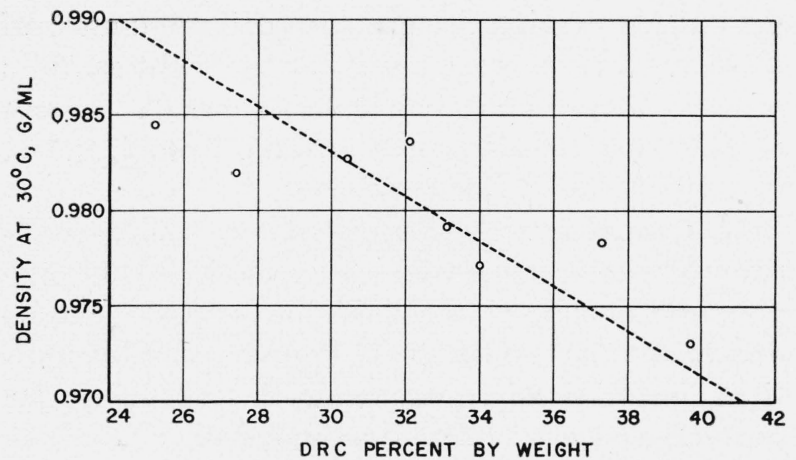

Figure 3.-Dry rubber content of latices as a function of the density.

The dotted curve is plotted from data of Rhodes [11] for Hevea latex. The points are experimental values obtained for mangabeira latex in the present investigation

of the latices as calculated from the densities. These values are to be compared with those determined by coagulation in the adjoining column to the right. It can be seen from figure 3 that the deviation of some of the points from the curve is quite great, but for approximate values of DRC the formula given for the latex of Hevea also can be applied to that of mangabeira.

It will be noted from the table that the true DRC and the density-calculated DRC for latex $\mathrm{H}$ are in good agreement with each other, but when this latex is diluted $1: 1$ with water (sample $0.5 \mathrm{H}$ ) its density-calculated DRC is much too high. This is because of the high density of the serum. In fact, pure water is calculated from the formula to have a DRC of 19.5 percent. Sample 37 is plotted in figure 2 from calculated values of the density at $30^{\circ} \mathrm{C}$ for a latex with 37 percent DRC. Values for the curve at other temperatures are calculated by using the coefficients of expansion of the rubber and water in their proper proportion for these other temperatures. The coefficient for rubber is practically constant over this range of temperature for purposes of this calculation, but the coefficient for the water changes so rapidly, especially at the lower temperatures, that the resulting curves for the latices are not linear. The shapes of all the experimental curves are very similar to that of the theoretically calculated curve 37 .

\section{Coagulating Agents}

As stated earlier in this paper there are a number of coagulating agents which will separate the mangabeira rubber from its serum, but only a few of these agents have any commercial possibilities. Acetic acid, for example, which is used in a concentration of less than 1 percent (commercial grade) for the coagulation of latex from the seringueira or Pará tree, must be added in much larger quantities in order to coagulate mangabeira latex. As shown in table 2, a concentration of $5 \mathrm{ml}$ of glacial acetic acid per 100 $\mathrm{ml}$ of latex is not sufficient for coagulation. Usually twice this concentration is sufficient if the latex has had no previous dilution. However, this is not always true, as in some cases at least 25 $\mathrm{ml}$ per 100 were necessary. There is some variability between different latices, but the data given in table 2 are typical and close to average. Complete coagulation can correctly be assumed if the resulting serum is not milky in appearance. Even a very small amount of rubber left in serum causes it to be noticeably milky. Coagulations with acetic acid, when they do take place, are quite rapid, requiring usually 15 to 20 minutes or less. Acetic acid coagulations give satisfactory results as a laboratory procedure for analysis of the DRC of mangaberia latex, but too much of this acid is required for industrial processing.

TABLE 2.-Results obtained from various coagulating agents on mangabeira latex

\begin{tabular}{|c|c|c|c|c|}
\hline \multicolumn{2}{|l|}{ Coagulant } & \multirow{2}{*}{$\begin{array}{l}\text { Water } \\
\text { added } \\
\text { to } 100 \\
\text { ml of } \\
\text { latex }\end{array}$} & \multirow[b]{2}{*}{ Serum condition } & \multirow{2}{*}{$\begin{array}{l}\text { Time } \\
\text { required } \\
\text { for } \\
\text { complete } \\
\text { coagula- } \\
\text { tion }\end{array}$} \\
\hline Type & $\begin{array}{l}\text { Added } \\
\text { to } 100 \\
\text { ml of } \\
\text { latex }\end{array}$ & & & \\
\hline & $m l$ & $m l$ & & Minutes \\
\hline Glacial acetic acid. & 5 & 0 & Quite milky $\ldots . . . .$. & - nn \\
\hline Do & 10 & 0 & Clear & 20 \\
\hline Do....... & 10 & 100 & Quite milky ...... & -.. \\
\hline Do & 10 & 200 & Very milky . . . . . . & $\ldots$ \\
\hline Do $\ldots . . .$. & 20 & 0 & Clear & 20 \\
\hline Do $\ldots$ & 20 & 100 & Somewhat milky...... & \\
\hline Do & 20 & 200 & Quite milky & -. \\
\hline Do & 30 & 0 & Clear............... & 15 \\
\hline Do & 30 & 100 & Slightly milky & -.. \\
\hline Do & 30 & 200 & do do . . _ _ & $\cdots$ \\
\hline Caxinguba latex & 2 & 100 & Somewhat milky & - \\
\hline Do & 4 & 100 & Clear & 60 \\
\hline Do & 8 & 100 & _._. do do & 25 \\
\hline Hydrochloric acid. & 0.1 & 100 & Somewhat milky & - \\
\hline Do & .25 & 100 & Clear & 600 \\
\hline Do & .5 & 100 & _. do do & 29 \\
\hline Do & 1 & 100 & _. do $d 0_{1}$ & 11 \\
\hline Do & 2 & 100 & $\ldots$.... do & 2 \\
\hline Do..... & 4 & 100 & _. do & 1 \\
\hline
\end{tabular}

It was found that hydrochloric and sulfuric acids in much smaller quantities coagulate manga- 
beira rubber equally well or even better. This can also be seen from table 2 . The degree of dilution of the latex does not have much effect on the quantity of acid required for coagulation. If there is no dilution and 10 or $20 \mathrm{ml}$ or more of concentrated hydrochloric acid are added, the rubber will coagulate completely, but the physical characteristics of the rubber are changed. For example, the rubber will crumble into small pieces when passed through a mixing mill and will have a slight pungent odor. However, small concentrations of the acid produce a rubber of good quality.

As can be seen from table 2, the concentration of the acid in the latex has a great effect on the time of coagulation. Although, for the particular sample of latex described in the table, 0.25 percent of commercial hydrochloric acid in the latex was sufficient for complete coagulation, experience has shown that it is safer to add 0.5 percent. For the factory coagulations conducted in connection with this work, 1 liter of water was first added to a liter of the latex, and then $5 \mathrm{ml}$ of the concentrated acid in $50 \mathrm{ml}$ of water were added. This produced a satisfactory coagulum, which was ready for rolling into sheet form in about 12 hours.

If the latex is not diluted before coagulation, or if the coagulation takes place in too short a time, the resulting coagulum is not as uniform and is much harder, thus making the sheeting process more difficult. Undiluted latex with a high DRC does not leave sufficient liquid for the coagulum to float, and the spongy solid phase, together with its absorbed serum, occupies the whole space from the surface of the coagulum to the bottom of the container and often sticks to the bottom. If the dilution is too great, or if too long a time is required for coagulation, the resulting coagulum is too weak for proper handling during the sheeting process. Complete coagulation within a few hours seems to give the most satisfactory product. After complete coagulation, it is advisable also to allow several hours for the coagulum to harden sufficiently. The proper amount of dilution allows the coagulum to form more slowly and uniformly and also to float on the surface of the liquid, thus facilitating the removal of the rubber phase. This makes the processing operation convenient for tapping and collection in the morning, addition of the coagulating agent in the early afternoon, and sheeting in the late afternoon or following morning.

Latex from the caxinguba tree (Ficus anthelmintica) acts as a coagulating agent for the latex of mangabeira. ${ }^{5}$ The caxinguba tree is found in the tropics of Brazil, in no great concentration in any one area, but quite widely distributed. Its latex can be recommended as an excellent coagulant for the latex of the mangabeira if the two trees are found in the same area. A lack of rapid and dependable transportation in the rubbergrowing areas may prevent the relatively unstable caxinguba latex from being transported over any great distances. The latex to be coagulated can be diluted 1:1 with water, and the caxinguba latex added either in its original or diluted state. About 5 percent concentration of latex is recommended, or about $50 \mathrm{ml}$ per liter of mangabeira latex. Incidentally, the latex of the caxinguba is also a very good coagulant for the latex of the Hevea, a much lower concentration of the coagulant being required than for mangabeira.

Alum solutions and sodium chloride solutions have been the coagulating agents used by the natives in the production of the mangabeira rubber. These salts were studied as coagulants in this investigation by adding them as 10-percent solutions. Both coagulants gave a nice looking coagulum that sheeted easily. The amount of coagulating agent usually used to insure complete coagulation was about $100 \mathrm{ml}$ of the 10 -percent solution per liter of the latex.

As stated earlier in this paper, partial coagulation of the rubber from mangabeira latex may take place from agitation, even though it is quite mild like that taking place in most laboratory stirring operations. In attempts made to concentrate the latex by means of a centrifuge, coagulation always took place. Guimaraes and Chaves [3] reported that their mangabeira latex could be coagulated by means of vigorous agitation. It seems quite probable that a successful commercial coagulation method may be developed based on this principle.

\section{Chemical Composition of the Rubber}

Not all the samples of rubber were analyzed, but table 3 shows the averages of the results

\footnotetext{
${ }_{5}$ Hugo Borborema, under the supervision of Felisberto C. de Camargo, director of the Instituto Agronômico do Norte, found that the latex of caxinguba was effective as a coagulant for the latex of mangabeira. Their experiments were conducted at the latex-processing factory of the Instituto Agronômico do Norte, and further study of this method of coagulation was turned over to the Rubber Laboratory.
} 
obtained. The resin content of the mangabeira rubber, which in most cases runs from 10 to 13 percent, is higher than that for the Hevea rubber, which is usually below 4 or 5 percent. The resin content is higher for a rubber prepared from latex by evaporation. This indicates that in ordinary coagulation some of the resins remain in the serum.

TABLE 3.-Results of analyses on dry coagulated mangabeira rubber

\begin{tabular}{|c|c|c|}
\hline Sample & Resins & Ash \\
\hline B $\ldots$ & $\begin{array}{l}\text { Percent } \\
\text { a10. } 6\end{array}$ & $\begin{array}{c}\text { Percent } \\
0.17\end{array}$ \\
\hline C.. & 11.5 & .20 \\
\hline D ... & 13.3 & .17 \\
\hline G... & 7.3 & .29 \\
\hline $\mathrm{H}$ & 6.7 & $\ldots$ \\
\hline$I_{\ldots} \ldots$ & 12.8 & .14 \\
\hline$J_{\ldots}$ & b9. 3 & .13 \\
\hline
\end{tabular}

a $13.0 \%$ resins on a sample of evaporated latex.

b $13.4 \%$ resins on a sample of evaporated latex.

In the five samples for which determinations of both DRC and resins were made there is indicated a trend that latices having a higher DRC yield a rubber of lower resin content. Whether or not this is generally true must be proved by similar analyses on many more samples of latex.

The ash content of mangabeira rubber (table 3 ) averages 0.2 percent, which is about the same as that usually found in Pará rubber. In a few instances, however, when the mangabeira rubber was coagulated by means of sodium chloride, the ash content was higher $(0.4$ to $0.6 \%)$. This should be expected because of the difficulty of washing out completely the coagulant from the coagulum. No doubt an alum coagulation leaves an equivalent amount of alum in the rubber, but this does not show up so strongly in the ash because over 70 percent of the absorbed alum is lost during the ignition process. More detailed analyses on mangabeira latex and rubber were made by Guimaraes and Chaves and published earlier [3].

\section{Physical Properties of the Rubber}

In order to evaluate the mangabeira rubber, especially as to its aging properties, tensile tests were made on both aged and unaged vulcanized samples. Samples of the mangabeira rubber coagulated by different means were also tested and compared with a typical sample of Hevea rubber.

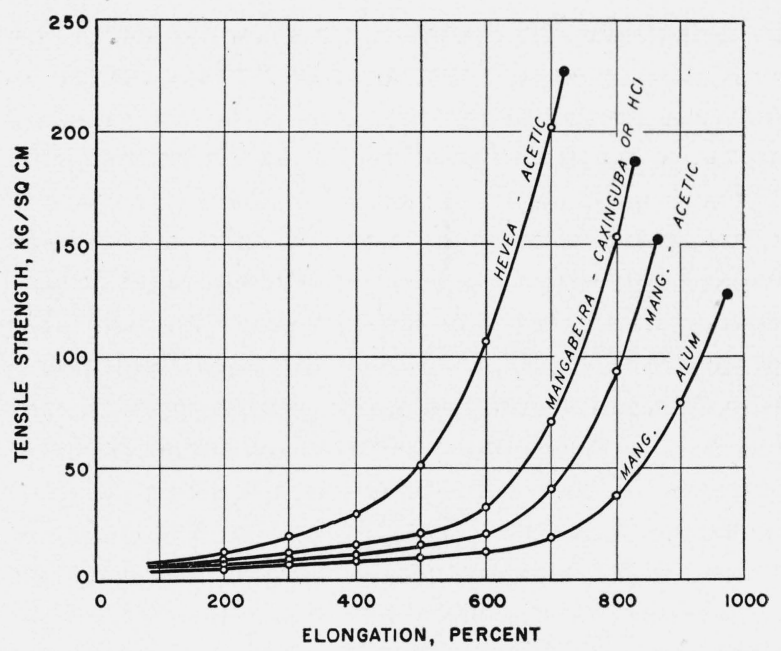

Figure 4.-Tensile properties of vulcanized Hevea rubber coagulated with acetic acid compared with mangabeira rubber coagulated by different agents.

Figure 4, which contains curves made from average values obtained from a number of tests and samples, shows that the Pará rubber has higher tensile properties than the mangabeira. The mangabeira rubber coagulated with caxinguba latex or with dilute hydrochloric acid gives tensile properties superior to those of samples coagulated with acetic acid or alum. The alum-coagulated rubber has the poorest properties of all. Actually, this evaluation may quite easily have been indicated without vulcanizing the rubber and determining its tensile properties. Rubber coagulated with alum is somewhat tacky and becomes much more so within several weeks time. The rubber coagulated with acetic acid is also tacky, but to a less degree. The rubber coagulated with the latex of caxinguba or with dilute hydrochloric acid exhibits no tackiness even over a period of a year or more.

The pinkish appearance which is characteristic of mangabeira latex is transferred to the rubber in all the processing methods described here. Mangabeira rubber can usually be distinguished from other types of rubber by this color.

Samples of unvulcanized mangabeira rubber coagulated by dilute hydrochloric acid or by caxinguba latex have been kept in the laboratory for over a year without any appreciable visual aging, as is indicated by their lack of tackiness. The other coagulants, especially the alum or the sodium chloride, cause the rubber to age quite rapidly. In less than 1 year the rubber becomes 
so sticky that it seems almost worthless. No doubt it is this poor aging quality that has given the mangabeira rubber its bad reputation. Laboratory aging tests were made by means of the oxygen bomb, as previously described. The stress at break for mangabeira rubber coagulated with the caxinguba or dilute hydrochloric acid in all cases decreased no more than 50 percent during the aging process. The rubber samples coagulated with the salts became so badly oxidized and brittle that in some cases they broke in pieces when bent by hand. Usually, they were too weak to test on the Scott tensile tester. A few that had enough resistance to be tested were found to have deteriorated from 80 to 90 percent with respect to tensile properties.

The coagulated rubber was always thoroughly washed during the sheeting process, but chemical analyses of the rubber indicate that the coagulating agents used in these experiments were not removed completely. It is out of the question to expect commercial washing to be more effective than these small-scale operations in freeing the rubber frem the small quantities of the coagulants or their impurities, which are probably the cause of the poor aging qualities of the mangabeira rubber.

\section{Summary and Conclusions}

1. Of a number of samples of latex of mangabeira investigated, the DRC values ranged from 25 percent to 40 percent, the average being about 33 percent.

2. A rough value of the DRC of mangabeira latex can be obtained by measuring its density and applying the same tables which are used for latex of the seringuira or Pará rubber-tree, assuming the law of mixtures on a volume basis, the density of the serum as 1.020 , and the density of the disperse phase as $0.9064 \mathrm{~g} / \mathrm{ml}$ at $30^{\circ} \mathrm{C}$.

3. The volume coefficient of expansion for the average mangabeira latex, which contains from 30 to 40 percent DRC, is about $0.00041 /{ }^{\circ} \mathrm{C}$.

4. Both for laboratory analyses for the DRC and for the commercial coagulation of mangabeira latex the best coagulants are either dilute hydrochloric acid (about $0.5 \%$ ) or the latex of the caxinguba (about $5 \%$ )

5. Alum and sodium chloride solutions, both of which at the present time are used as coagulating agents in the commercial production of mangabeira rubber, have a degrading effect on the resulting product, both unvulcanized and vulcanized.

6 . The resin content of the mangabeira rubber is usually from 7 to 13 percent, most values being closer to the latter. The ash content is usually quite low, about 0.2 percent.

7. The optimum conditions for vulcanization of mangabeira rubber, as determined by the highest tensile strength, are from 60 to 90 minutes at $141^{\circ} \mathrm{C}$ when compounded according to formula II of the Crude Rubber Committee of the Rubber Division of the American Chemical Society.

8. Mangabeira rubber is softer and weaker than Hevea rubber, but with the improved methods of processing, the physical and aging properties of the mangabeira rubber have been greatly improved, and this rubber may find commercial applications in the future, especially as a specialpurpose rubber.

9. There are possibilities that still another method of coagulating rubber from mangabeira latex, making use of vigorous agitation, may be developed.

\section{References}

[1] E. G. Holt, private communication.

[2] A. W. J. Dyck, private communication.

[3] L. R. Guimarães and J. M. Chaves, Coagulation of the latex of Mangabeira. Rev. brasil. quim. (São Paulo) 18, 130 (1944).

[4] A. S. T. M. Standards, 1942. Part III, American Society for Testing Materials, 1916 Race St., Philadelphia 3, Pa.

[5] Report of the Crude-Rubber Committee, Rubber Chem. Tech. 17, 529 (1944).

[6] O. deVries, Estate rubber: Its preparation, properties, and testing, p. 38 to 42,111 to 121 (Drukkerijen Ruygrok \& Co., Batavia, 1920).

[7] E. A. Hauser and W. J. Kelly, Latex: Its occurrence, collection, properties, and technical applications, p. 68, 70, 71 (The Chemical Catalog Co., New York, N. Y., 1930).

[8] P. Scholz and K. Klotz, Contributions to the chemistry of latex, Kautschuk $\boldsymbol{\gamma}, 142$ (1931).

[9] E. Rhodes, The specific gravity of preserved latex, J. Rubber Research Inst. Malaya 5, 234 (1934); Rubber Chem. Tech. 8, 284 (1935).

[10] O. deVries, The specific gravity of rubber in latex, India-Rubber J. 89, 343 (1935).

[11] E. Rhodes, The specific gravity of preserved latex, India-Rubber J. 89, 397 (1935).

[12] H. P. Stevens and son, Specific gravity of rubber in latex, India-Rubber J. 87, 400 (1935). 
[13] E. Schmidt and P. Stamberger, Some properties of rubber latex, Rec. Commun. Congr. Int. Caoutchouc, Paris, p. 42 (1937).

[14] N. Bekkedahl and L. A. Wood, Crystallization of vulcanized rubber, Ind. Eng. Chem. 33, 381 (1941); Rubber Chem. Tech. 14, 347 (1941).

[15] H. L. Curtis, A. T. McPherson, and A. H. Scott, Density and electrical properties of the system, rubber-sulfur, NBS Scientific Papers 22, 383 (1927) S560.

[16] L. A. Wood, Values of the physical constants of rubber, Proc. Rubber Tech. Conf. London, England, p. 933 (1938); Rubber Chem. Tech. 12, 130 (1939).
H. Fairfield Smith, Specific gravity of latex and rubber, J. Rubber Research Inst. Malaya 9, 218 (1940) ; Rubber Chem. Tech. 13, 485 (1940).

G. E. van Gils, The specific gravity of rubber and of serum in Hevea latex, Arch. Rubbercultuur 23, 130 (1939); Rubber Chem. Tech. 13, 422 (1940).

O. deVries, The specific gravity of rubber in latex, IndiaRubber J. 98, 422 (1939); Rubber Chem. Tech. 13, 130 (1940).

Washington, November 1, 1946 